\title{
Upregulation of IGF-2 and IGF-1 receptor expression in oral cancer cell lines
}

\author{
GARRETT BRADY $^{1}$, STJOHN CREAN ${ }^{2}$, PRASHANT NAIK $^{3}$ and SUPRIYA KAPAS ${ }^{3}$ \\ ${ }^{1}$ Department of Oral and Maxillofacial Surgery, Leeds Dental Institute, Clarendon Way, Leeds LS2 9LU; \\ ${ }^{2}$ Department of Oral and Maxillofacial Surgery, North Glamorgan Trust, Prince Charles Hospital, \\ Merthyr Tydfill, CF47 9DT; ${ }^{3}$ Clinical and Diagnostic Oral Sciences, Barts and the London, \\ Queen Mary School of Medicine and Dentistry, Newark Street, London E1 2AD, UK
}

Received April 30, 2007; Accepted June 28, 2007

\begin{abstract}
The insulin-like growth factors (IGFs) are a family of mitogenic proteins involved in the regulation of cell growth and differentiation. The presence and role of the IGF system in oral mucosal epithelium is not clear but could influence our understanding of the pathogenesis of oral cancer. We characterised the expression and function of IGF-1, IGF-2 and IGF receptor in human oral squamous carcinoma cell lines and normal oral epithelial cells as well as normal oral and squamous cell carcinoma tissues. Using reverse transcription followed by PCR, IGF-1 mRNA was only detected in normal cells, whereas IGF-2 and IGF-1R mRNA transcripts were highly expressed in tumour cell lines and tissues. Similar observations were seen by Western blot analysis and immunohistochemistry. Exogenous IGF-2, but not IGF-1, caused significant increases in DNA synthesis in the cell lines. IGF-2 also increased cell proliferation which was significantly attenuated in the presence of an IGF-2 neutralizing antibody or one which blocked IGF-1R. Taken together, these studies suggest that autocrine production of IGF-2, together with over-expression of IGF-1R, may be important components controlling the proliferation of oral carcinoma cells.
\end{abstract}

\section{Introduction}

The insulin-like growth factor (IGF) family of proteins is thought to play an important role in regulating cell proliferation, differentiation and apoptosis and as such there

Correspondence to: Dr Garrett Brady, Maxillofacial Department Leeds Dental Institute, Clarendon Way, Leeds LS2 9LU, UK

E-mail: garrettbrady@hotmail.com

Key words: insulin-like growth factors, insulin-like growth factor receptor, oral squamous cell carcinoma, oral epithelial cells, DNA synthesis is considerable accumulating evidence indicating that it may also be important in promoting carcinogenesis. This is deemed to occur by increasing the risk of cellular turnover and thus increasing the susceptibility of cells to malignant transformation (1-4). The IGF family consists of polypeptide ligands IGF-1 and -2 which are synthesized mainly in the liver. IGF-1 and -2 are present in the circulation in combination with binding proteins (IGFBPs) of which 6 have been identified, IGFBP-1 to IGFBP-6 (5-8). Both IGF-1 and -2 exert their effects by binding to a transmembrane tyrosine kinase receptor, IGF-1R, which is structurally and functionally related to the insulin receptor (IR) (9).

Several studies, both experimental and clinical, have demonstrated that the IGF-1R is over-expressed in tumours compared to normal tissues $(3,10,11)$. Furthermore, epidemiological prospective studies have identified high plasma levels of IGF-1 as a potential risk factor for several malignancies (12-15). In addition, IGF-2, whose expression normally is strictly controlled by parental imprinting, is upregulated and functions as an important stimulant of the IGF-1R in cancer $(16,17)$. Thus, upregulation of IGF-1R and its ligands are probably important events for the malignant cell growth.

The role of IGF in the development of oral carcinomas is less clear. One study failed to establish a predictive link for serum levels of IGF-1 in carcinomas of the tongue (17). In contrast, recent work has demonstrated a clear association between high circulating levels of IGF-1 and high or low levels of IGFBP-3 with the development of second primary tumour in the head and neck (18). Work from our group has recently shown that oral cancer seems to be associated with reduced levels of serum IGF-1 and IGFBP-3, with elevated levels of IGFBP-1 and -2 (19). To know how IGFs act on oral epithelium could have an important impact in understanding the pathogenesis of oral cancer. Whilst there have been studies describing the presence of the IGF system in tooth growth and development (20-22), we are not aware of any studies on oral mucosal epithelial cells.

The aim of this study was to characterise IGF-1, IGF-2, and IGF-1R by investigating their expression and function in human oral epithelial cancer cell lines and normal cells maintained in short-term culture. 


\section{Materials and methods}

Reagents. All cell lines used were derived from oral squamous cell carcinomas. SCC-4 and SCC-25 were both derived from tongue epithelia, FaDu from the pharynx and TR146 from the buccal mucosa. Cell culture media (DMEM for SCC-4, -25, TR146 and FaDu cells, and KGM Bullet Kit for NOK cells) were purchased from Cambrex Bio-Science (Wokingham, UK). Reagents for reverse transcription and PCR were purchased from Invitrogen (Paisley, UK). Antibodies to human IGF-1 (AF-291-NA), IGF-2 (MAB292) and IGF-1R (MAB391) were purchased from R\&D Europe Systems (Oxon, UK) as were IGF-1 and IGF-2 recombinant proteins (291-G1 and 202-G2, respectively). Primer pairs for the detection of IGF-1, -2 or IGF-1R were obtained from Invitrogen based on Neuvians et al (23). All other reagents were the best available grade and purchased from SigmaAldrich (Poole, Dorset, UK).

Cell maintenance and treatments. None of the cells used required $3 \mathrm{~T} 3$ feeder cells for growth. SCC-4 and -25 cells were maintained in $775 \mathrm{~cm}^{2}$ tissue culture flasks with DMEM supplemented with $10 \%$ fetal bovine serum (FBS), $400 \mathrm{ng} / \mathrm{ml}$ hydrocortisone and routine antibiotics in a humidified atmosphere containing $5 \% \mathrm{CO}_{2}$ and $95 \%$ air at $37^{\circ} \mathrm{C}$. Medium was removed and replaced every 2-3 days. FaDu and TR146 cells were maintained as described above but in medium without hydrocortisone. Normal oral keratinocytes (NOK) were acquired from the departmental archive of frozen cells (CDOS, Queen Mary University, London). They were taken from normal oral mucosa at the time of third molar surgery in 1995 and frozen at the time of first passage. NOK were maintained in KGM supplemented with the manufacturer's Bullet Kit which consisted of hydrocortisone, insulin, epidermal growth factor (EGF), bovine pituitary extract (Cambrex).

Forty-eight hours before experiments were carried out cells were placed into 6-well cell culture plates for $24 \mathrm{~h}$ in full medium. Twenty-four hours before experiments were carried out cells were rendered quiescent by placing them in serum-free medium (or in the case of NOK cells in Bullet Kit-free medium). On the day of experiments, cells were washed in sterile PBS and incubated with $1 \mu \mathrm{Ci} / \mathrm{ml}\left[{ }^{3} \mathrm{H}\right]-$ thymidine (Amersham Pharmacia Biotechnology, Amersham, UK) in the absence and presence of $10^{-8} \mathrm{M}$ IGF- $1,10^{-8} \mathrm{M}$ IGF-2 or $10 \%$ serum for $24 \mathrm{~h}$. DNA was precipitated with $5 \%$ trichloroacetic acid and solubilised in $0.1 \mathrm{M} \mathrm{KOH}$. An aliquot was taken for liquid scintillation counting in a liquid scintillation counter. In other experiments, untreated cells from 6-well plates were taken for Western blot analysis.

Cell proliferation assay. The effect of IGF- 2 on the proliferation of NOK, SCC-4, SCC-25, FaDu and TR146 cells were studied. Cells were maintained as described above and were seeded at a density of 5,000 cells per well into a 24-well plate and incubated overnight. The next day cells were incubated in the presence of serum-free media and left to incubate for a further $24 \mathrm{~h}$ before being treated with medium alone, $10 \mu \mathrm{g} / \mathrm{ml} \mathrm{IGF-2} \mathrm{neutralising} \mathrm{antibody,}$ $1 \mathrm{mg} / \mathrm{ml}$ recombinant IGF-2 protein or $10 \mu \mathrm{g} / \mathrm{ml} \mathrm{IGF-1R}$ blocking antibody placed $2 \mathrm{~h}$ before addition of $1 \mathrm{mg} / \mathrm{ml}$ recombinant IGF-2 protein for further $4 \mathrm{~h}$. These experiments were repeated three times.

Cell proliferation was determined using the MTT assay. Serum-free medium $(200 \mu \mathrm{l})$ was pipetted into the wells and cells were incubated for $4 \mathrm{~h}$ with $20 \mu \mathrm{l}$ of $5 \mathrm{mg} / \mathrm{ml} \mathrm{MTT}$ solution (w/v in sterile PBS). Medium was then carefully aspirated and the formazan product was dissolved by adding $500 \mu 1$ DMSO to each well. Plates were shaken gently on a plate shaker for $15 \mathrm{~min}$. Each sample $(200 \mu \mathrm{l})$ was placed in a 96-well plate using DMSO as assay blanks. Absorbance was read at $570 \mathrm{~nm}$ using a microplate reader.

RNA extraction from formalin-fixed, paraffin-embedded tissue. Formalin fixed, paraffin-embedded tissue of 10 oral tumours and 10 normal oral mucosa tissues were obtained with Research Ethics Committee (REC) approval (St. James' Hospital and Federated Dublin Voluntary Hospitals Joint REC, reference 020512/8602). RNA was extracted from tissues following published methods (24). To 20 micron sections of tissue $100 \mu 1$ of $0.5 \%$ Tween-20 was added, agitated and heated to $90^{\circ} \mathrm{C}$ for $10 \mathrm{~min}$ in a Thermal Cycler (Jencons Ltd., East Sussex, UK). Samples were then digested with $2 \mu \mathrm{l}$ of $10 \mathrm{mg} / \mathrm{ml}$ Proteinase $\mathrm{K}$ for $3 \mathrm{~h}$ at $55^{\circ} \mathrm{C}$ with gentle agitation every $60 \mathrm{~min}$. Each digest mixture was then heated to $99^{\circ} \mathrm{C}$ for $10 \mathrm{~min}$ with $100 \mu 15 \%$ Chelex-100 (Bio-Rad) in Tris-EDTA. Samples were gently shaken and immediately centrifuged at $12,000 \mathrm{rpm}$ for $15 \mathrm{~min}$ and then placed on ice to harden the wax. The wax was lifted out of the tubes and the sample heated to $45^{\circ} \mathrm{C}$ and $100 \mu 1$ chloroform added. Tubes were gently flicked to mix contents before further centrifugation. The top phase (about $150 \mu \mathrm{l}$ ) was removed and stored at $-70^{\circ} \mathrm{C}$ until required. Extracted RNA (5 $\mu \mathrm{l})$ was subsequently used for RT-PCR.

$R T$-PCR . Total cellular RNA was isolated by acid guanidinium thiocyanate-phenol-chloroform extraction using Ultraspec solution (AMS Biotechnology, Abingdon, UK) following manufacturer's instructions. Reverse transcription of the RNA and subsequent PCR was carried as described previously (25). For PCR the following oligonucleotide primers were used: IGF-1 sense 5'-cgcatctcttctatctgg-3' and anti-sense 5 '-gcagtacatctccagcctcc-3' (product size $260 \mathrm{bp}$ ); IGF-2 sense 5'-gaccgcggcttctacttcag-3', antisense 5'-aagaa cttgcccacggggtat-3' (product size 203 bp); IGF-1R sense 5'-ttaaaatggccagaacctg-3', antisense 5'-attataaccaagcctcccac-3' (product size $314 \mathrm{bp}$ ) and GAPDH sense: 5'-ccacagtccatgc catcac-3' and antisense: 5'-tccaccacctgttgctgta-3' (product size $420 \mathrm{bp}$ ). The reaction cycles of PCR were 40 cycles denaturation for $30 \mathrm{sec}$ at $94^{\circ} \mathrm{C}$, primer annealing for $1 \mathrm{~min}$ at $65^{\circ} \mathrm{C}\left(54^{\circ} \mathrm{C}\right.$ for GAPDH) and primer extension for $1 \mathrm{~min}$ at $72^{\circ} \mathrm{C}$. PCR products were separated by electrophoresis in a $0.8 \%$ agarose gel stained with ethidium bromide. Bands were visualized under ultraviolet light.

Measurement of IGF-1 and -2 secretion. IGF-1 and IGF-2 secretion in conditioned media of untreated cells were quantitated by ELISA following manufacturer's instructions (Oxford Bio-Innovation Ltd., Oxon, UK). Cells were seeded at $1 \times 10^{6}$ cells/well in 6 -well cell culture plates for $24 \mathrm{~h}$ to 


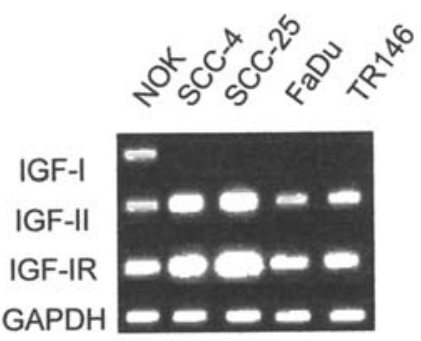

Figure 1. mRNA expression of IGF-1, -2 and $1 \mathrm{R}$ in oral epithelial cells. Semi-quantitative RT-PCR mRNA expression of IGF-1, IGF-2, IGF-1R and housekeeping gene GAPDH in a normal human oral epithelial cell line (NOK) and squamous carcinoma cell lines.

72 h. Conditioned media were collected 24,48 and 72 h, stored at $-20^{\circ} \mathrm{C}$ and later analyzed for IGF-1 and -2 .

Immunohistochemistry. Archival formalin-fixed paraffinembedded tissue samples of 15 human oral squamous cell carcinomas were used for immunohistochemistry (REC reference as above). Sections $(5 \mu \mathrm{m})$ were deparaffinised and rehydrated in xylene followed by graded alcohols. Sections were treated as described previously (26) except antigen retrieval was carried out by microwaving for $9 \mathrm{~min}$ in $0.01 \mathrm{M}$ citrate buffer. Antibodies used were from Abcam (Cambridge, UK): rabbit polyclonal to human IGF-1 (ab15320) used undiluted, rabbit polyclonal to human IGF-2 (ab9674) used at 1:100; rabbit polyclonal to human IGF-1R (ab30657) used at 1:20. The secondary antibody and subsequent detection was carried out at room temperature using the LSAB + System-HRP kit following manufacturer's instructions (Dako Ltd., Ely, UK).

Western blot analysis. After treatment cells were lysed and proteins extracted, electrophoresed, transfered to a PVDF membrane and blotted as described previously (26). Antibodies used are listed in the reagents section and used at 1:1,000 dilution. Blots were analysed by densitometry (Kodak 1D 3.5 software, version 1; UVP International, Cambridge, UK).

Statistical analysis. The data were analyzed using the SPSS 7.5 Windows Students version software. For all the measurements, one-way ANOVA followed by Student's Newman Keuls (SNK) test was used to assess the statistical significance. Experiments were performed in triplicate.

\section{Results}

$I G F-1, I G F-2$ and IGF-1R are highly expressed in oral cancer cell lines. IGF-1, -2 or IGF-1R expression was measured by RT-PCR and were found to be differentially expressed in the cell lines used. The cells were deprived of serum/growth factors $24 \mathrm{~h}$ before experiments. Fig. 1 illustrates that only the normal oral epithelial cells, NOK, expressed a transcript for IGF-1. None of the oral squamous carcinoma cell lines used in this study expressed IGF-1 mRNA regardless of PCR cycle number or increasing the amount of starting RNA in the reverse transcription reaction (data not shown). In contrast, all cells expressed IGF- 2 mRNA, as can be

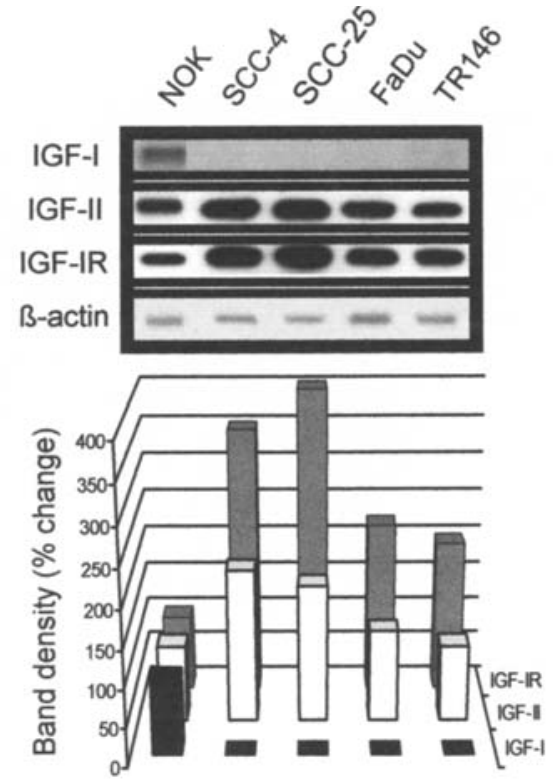

Figure 2. Representative Western blot analysis of IGF signaling components in human oral epithelial cell lines. Upper panel, cell extracts were immunoblotted for human IGF-1, IGF-2 or IGF-1R. B-actin antibody was used to determine protein loading control. Lower panel, bars show mean protein levels quantified densitometrically in relation to $\beta$-actin. Filled bars, IGF-1; striped bars, IGF-2; empty bars, IGF-1R. NOK cell protein level in relation to $B$-actin was designated $100 \%$ and differences in protein expression compared to this. Values are means \pm SEM $(n=3)$. SCC-4, SCC-25, FaDu and TR146 cells expressed no measurable levels of IGF-1. SCC-4, SCC-25 and FaDu expressed high IGF-2 levels ( $\mathrm{P}<0.05$ compared to NOK). All oral cancer cells expressed high levels of IGF-1R protein $(\mathrm{P}<0.01$ compared to $\mathrm{NOK}$ ).

seen in Fig. 1, with lower message levels in NOK, FaDu and TR146 cells. Fig. 1 also demonstrates that all cells expressed IGF-1R, with the squamous carcinoma cell lines SCC-4 and -25 having higher levels of expression.

The experiment were repeated for protein levels and analysed by Western blot. The results are very similar to the RT-PCR data described above. The upper panel of Fig. 2 illustrates that NOK cells expressed IGF-1 protein but none of the carcinoma cell lines were detectable. All cells expressed IGF-2 protein, with slightly higher levels in cell lines SCC-4 and -25. Fig. 2 also clearly shows that all cells expressed IGF-1R protein with over-expression in SCC -4 and -25 cells. The lower panel of Fig. 2 is a graphic representation of densitometry data from repeated Western blot experiments.

Expression of $I G F-1, I G F-2$ and $I G F-1 R$ in oral cancer tissues. We studied the expression of IGF-1, -2 and IGF-1R in oral cancer by immunocytochemistry and semi-quantitative RT-PCR. In normal tissue, we found there was weak immunoreactivity for IGF-1, IGF-2 or IGF-1R (data not shown) by immunohistochemistry. However, in oral squamous cell carcinoma, of which Fig. 3 is illustratative, there was increased immunoreactive IGF-1 and IGF-2 and IGF-1R in particular. We then extracted RNA from a number of archival tissues of histologically normal and OSCC tissue and performed RTPCR. Fig. 4 illustrates that there was expression of IGF-1, IGF-2 or IGF-1R message in normal tissues but this was increased at least 2-fold in OSCC. 


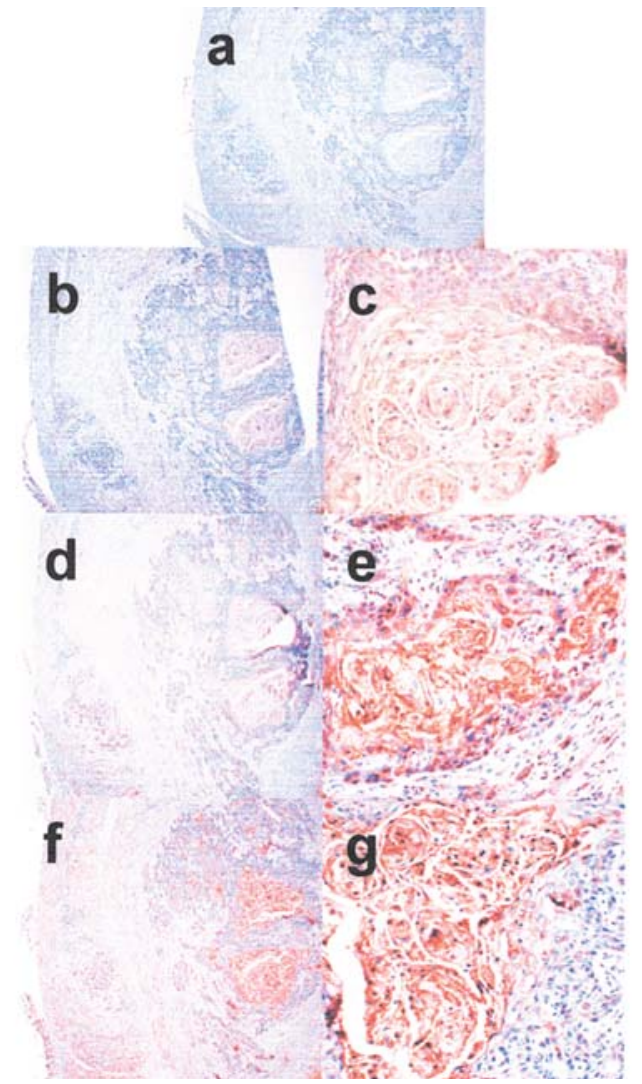

Figure 3. Immunohistochemical detection of IGF-1, IGF-2 or IGF-1R expression in human oral squamous cell carcinoma. (a) No antibody treatment (x40). (b) Weak positive immunostaining for IGF-1 (x40). (c) Weak positive immunostaining for IGF-1 (x200). (d) Positive immunostaining for IGF-1R (x40). (e) Positive immunostaining for IGF-1R (x200). (f) Positive immunostaining for IGF-2 (x40). (g) Positive immunostaining for IGF-2 (x200).

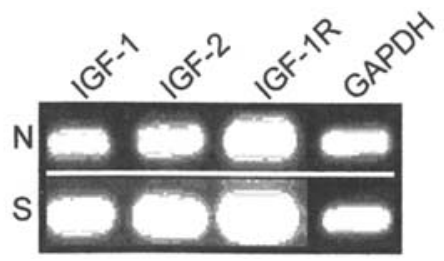

Figure 4. IGF-1, IGF-2 or IGF-1R mRNA expression in normal oral or squamous cell carcinoma tissues. Semi-quantitative RT-PCR mRNA expression of IGF-1, IGF-2, IGF-1R and housekeeping gene GAPDH in normal human oral buccal mucosa $(\mathrm{N})$ or squamous cell carcinoma tissues $(\mathrm{S})$.

Effect of exogenous IGFs on cell proliferation. In another series of experiments the secretion of IGF-1 or -2 from unstimulated cells was measured. Fig. 5a illustrates that only the normal oral cells produced significant levels of IGF-1 which increased with time over the 72-h period measurements were taken. Maximum secretion occurred at $48 \mathrm{~h}$ with $30 \pm 2.5$ ng/ml IGF-1 secreted. SCC-4, -25, FaDu or TR146 cells did not secrete IGF-1 significantly at any of the time points measured. Fig. 5b shows that all cells secreted IGF-2 with basal levels around $17.5 \pm 2.4 \mathrm{ng} / \mathrm{ml}$. The SCC cell lines produced the most IGF-2, with peak secretion at $48 \mathrm{~h}$ and the normal oral epithelial cells, FaDu and TR146 cells producing up to 3 -fold more IGF-2 compared to time point zero.
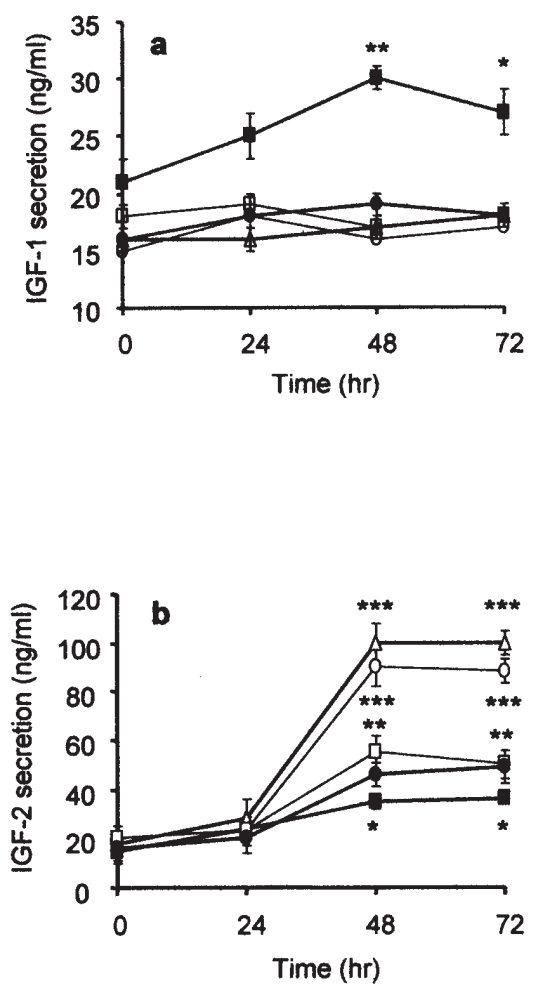

Figure 5. IGF-1 and IGF-2 secretion from human oral epithelial cell lines over $72 \mathrm{~h}$. Secretion of (a) IGF-1 secretion or (b) IGF-2 was measured by ELISA over a 72-h period. NOK, filled squares; FaDu, open squares; TR-146, filled circles; SCC-4, open circles; SCC-25, open triangles. Values are means \pm SEM $(n=3) .{ }^{*} \mathrm{P}<0.05,{ }^{* *} \mathrm{P}<0.01,{ }^{* * *} \mathrm{P}<0.001$ compared to IGF secretion time point zero (ANOVA).

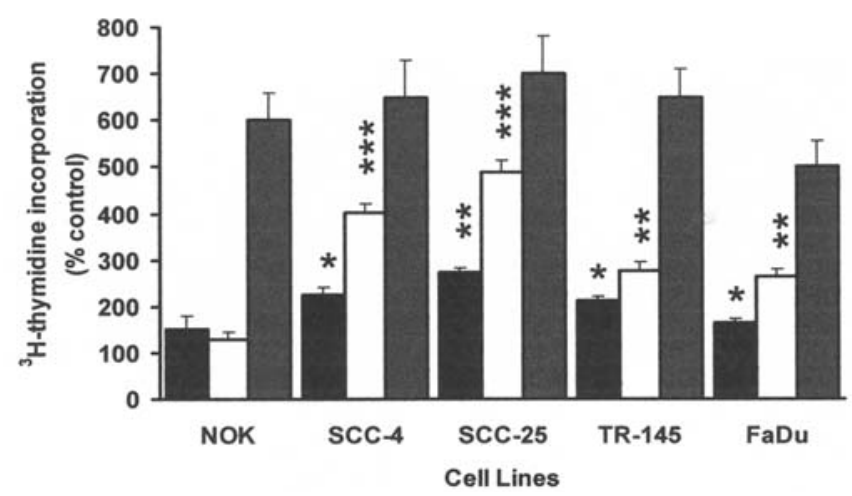

Figure 6. $\left[{ }^{3} \mathrm{H}\right]$-thymidine incorporation in oral epithelial cells. Confluent cultured cells were incubated at $37^{\circ} \mathrm{C}$ for $24 \mathrm{~h}$ in serum-free medium in the presence of $1 \mu \mathrm{Ci}\left[{ }^{3} \mathrm{H}\right]$-thymidine and $10^{-8} \mathrm{M}$ IGF-1 (open bars); $10^{-8} \mathrm{M}$ IGF-2 (filled bars) or $10 \%$ serum (stripped bars). Values are means \pm SEM $(\mathrm{n}=3) .{ }^{*} \mathrm{P}<0.05,{ }^{* *} \mathrm{P}<0.01,{ }^{* * *} \mathrm{P}<0.01$; compared to NOK (ANOVA).

DNA synthesis was studied by $\left[{ }^{3} \mathrm{H}\right]$-thymidine incorporation experiments. Fig. 6 illustrates that IGF-1 caused some increases in DNA synthesis in OSCC cells with the greatest levels in SCC-4 and SCC-25 cells. IGF-2 caused a significant increase in all the oral tumour cell lines used. Normal epithelial cells did not respond to either IGF-1 or -2 . Adding serum caused significant incorporation of $\left[{ }^{3} \mathrm{H}\right]-$ thymidine in all cells used.

It was evident (Fig. 5) that the oral cancer cell lines synthesised and secreted significantly more IGF-2 endo- 


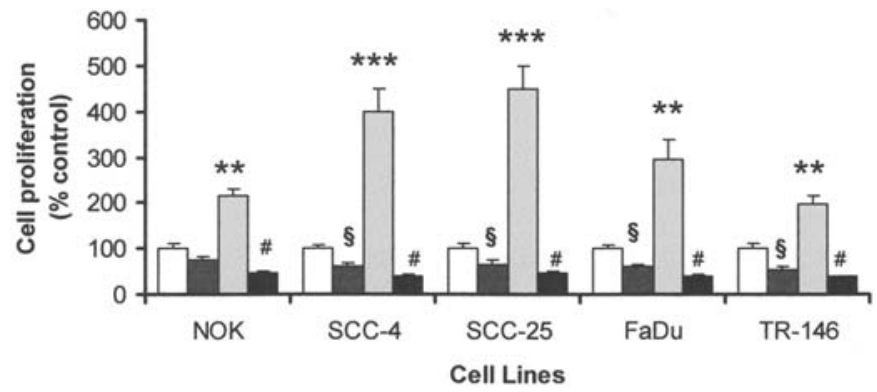

Figure 7. Effect of neutralizing antibodies on IGF-2-stimulated cell proliferation. Cells were incubated in the absence of presence of $10 \mu \mathrm{g} / \mathrm{ml}$ IGF-2 neutralizing antibody, $1 \mathrm{mg} / \mathrm{ml} \mathrm{IGF-2} \mathrm{recombinant} \mathrm{protein,} \mathrm{or} 10 \mu \mathrm{g} / \mathrm{ml}$ IGF-1R blocking antibody for $2 \mathrm{~h}$ prior to exposure to $1 \mathrm{mg} / \mathrm{ml}$ recombinant IGF-2 protein for a further $4 \mathrm{~h}$. Cell proliferation was measured using MTT and expressed as \% change versus basal cell growth. Empty bars, basal (48 h untreated) cell growth was taken as $100 \%$; stripped bars, anti-IGF-2 neutralizing antibody; spotted bars, recombinant IGF-2 protein; filled bars, anti-IGF-1R blocking antibody followed by recombinant IGF-2 protein. Values are means \pm SEM $(n=3) .{ }^{* *} \mathrm{P}<0.05 ;{ }^{* * *} \mathrm{P}<0.01$ compared to basal cell growth (ANOVA); ${ }^{\S} \mathrm{P}<0.05$ compared to basal cell growth (ANOVA); ${ }^{\#} \mathrm{P}<0.01$ compared to IGF-2-stimulated growth (ANOVA)

genously than IGF-1. It was decided to look further at the effect of IGF-2 on cell proliferation and whether this was mediated via the IGF-1R. Fig. 7 illustrates that after 48-h incubation in the presence of an IGF-2 neutralizing antibody there was significant attenuation of cell proliferation in all cancer cell lines, but not NOK. In the presence of exogenous IGF-2 there was between 2- and 4-fold increases in cell proliferation compared to basal control (i.e. no treatment). When cells were pre-treated with an IGF-1R blocking antibody before incubation with the IGF-2 neutralizing antibody, proliferation of all cells was significantly attenuated when compared to basal control.

\section{Discussion}

We found that normal and oral tumour epithelial cells express IGF-2 and IGF-1R mRNA transcripts and protein, whereas only normal epithelial cells expressed IGF-1 mRNA and protein. To our knowledge, this is the first study to demonstrate the abundance of IGF-2 and IGF-1R in human oral epithelial cells. At concentrations known to activate their receptors, IGF-1 had no effect on DNA synthesis, but IGF-2 caused significant increases in $\left[{ }^{3} \mathrm{H}\right]$-thymidine incorporation.

Studies looking at the role of IGFs and receptor in oral epithelium have been sadly lacking, though there have been a number of clinical studies. Free IGF-1 and -2 have been measured in human saliva (27) and the IGF-1 signaling axis is known to have a role in the developmental regulation of structures of the oral cavity $(20,28,29)$. In this study, we have investigated the expression of IGFs and IGF-1R in oral epithelial cells, both normal and squamous carcinomaderived in order to determine the role of the IGF system in oral cancer. We found IGF-1 mRNA and protein was only expressed in normal cells but not in any of the oral cancer cell lines used in this study. This lack of IGF-1 expression in oral cancer cells is an interesting observation but its meaning is not clear since there was no previous data in oral epithelial tissue to be compared with. A study by Tsai and co-workers
(22) noted IGF-1 mRNA in fibroblasts cultured from biopsies from patients with oral submucous fibrosis, a pre-cancerous condition. However, studies by Steller and co-workers $(30,31)$ demonstrated that primary cultures of normal and cancerous human cervical epithelial cells did not express IGF-1 mRNA or protein. One of the most important roles of IGF-1 action is that it acts as an anti-apoptotic factor hence the peptide is a cell survival agent $(1-4,10,15)$. It is tempting to speculate that the apparent loss of IGF-1 expression in the oral squamous carcinoma cells may play a role in malignant transformation in cancers of the head and neck. Indeed, previous studies from our group, reported that head and neck cancer patients had reduced serum levels of IGF-1 (and IGFBP-3) (19). It is well documented that IGF, as well as having an important role in normal growth, is also crucial in malignancy. This view is supported by clinical and in vitro studies where many observations have been reported of over-expression of IGFs and receptors in primary tumors and transformed cell lines $(12-15,32)$.

Like IGF-1, IGF-2 has a similar role in development and acts as an autocrine growth factor in a variety of cell types. To our knowledge, this is the first study to demonstrate that oral epithelial cell lines express IGF-2 transcript and protein, and that all cells secreted modest amounts of IGF-2 over time, in the absence of stimuli. Over-expression of IGF-2 appears to be strongly associated with neoplastic transformation of some types of epithelial cells and cancers (33-36). We found that the squamous carcinoma cell lines consistently expressed higher levels of IGF-2 transcripts and protein. These cells also responded to exogenous IGF-2, but not IGF-1, by significantly increasing DNA synthesis. This was further confirmed by studying cell proliferation. Fig. 6 illustrates that addition of exogenous IGF-2 significant increased cell proliferation of cells, the SCC in particular. A large component of the increase was due to IGF-2 and mediated via IGF-1R specifically, use of neutralizing IGF-2 or IGF-1R blocking antibodies attenuated cell proliferation significantly.

The SCC cell lines are derived from tumors of the oral cavity and have been described as being 'aggressive' cells $(37,38)$. A comprehensive study by Gasparoni et al (39) have suggested that these cells are more invasive than other tumorderived epithelial cells due to increased levels of E-cadherin and involucrin, and morphological changes characteristic of aggressive differentiation. We suggest that because these SCC cells, in particular, express high levels of IGF-2 this may contribute to oral cancer development or growth. In fact, a recent study has identified increased levels of IGF-2 as a biomarker for head and neck squamous cell carcinomas (40).

The implication of our findings is that the IGF-1R may also play an important role in rescuing cells from apoptosis. Blockade of the IGF-1R has been demonstrated to inhibit tumour cell growth and invasion in some cancers and has been targeted for possible therapeutic intervention (41-44). All cell lines used in this study expressed increased levels of transcripts and protein for IGF-1R compared to normal oral epithelial cells, more so in the SCC lines. The effects mediated by the interaction of IGF- 1 and IGF-1R are dependent on the levels of IGF-I receptor expressed on the 
cell surface. As the number of receptors increases, so does the effect that IGF-I exerts (45). With enough IGF-1 receptor activity, the signaling effects become mitogenic. It is believed that IGF-1 receptor expression is essential for the emergence of malignant transformation (46). The enhancement of IGF-1 receptor activity can be a result of increased receptor number, increased receptor stimulation, or both. It is tempting to speculate that such events are occurring in OSCC. Figs. 1 and 2 clearly illustrate the increased expression of IGF-1R, at both mRNA and protein level in oral cancer cell lines, but not normal cells. In vivo, Figs. 3 and 4 demonstrate normal oral epithelial tissue express some IGF-1, IGF-2 or IGF-1R message which was increased in tumour tissues.

Cellular over-expression of IGF-1R means an increased likelihood of a cell's survival and it makes sense for the squamous carcinoma cell lines to have higher levels of IGF-1R. The findings in this study can be added to the many published observations which have suggested that transformed cells in breast, prostate, cervical and other tumor types, express higher levels of IGF-1R than normal cells. How this occurs on a molecular level in tumour cells is not clear.

Logically, it seems clear that cells can increase their chances of survival by modulating IGF signaling in a number of ways. For example, increasing ligand production, increased expression of IGF-1R or decreased levels of IGFBPs which compete with IGFs to bind to the receptor. This study did not investigate the role of IGFBPs in these cells but this is currently underway. Nevertheless, these experiments lend further evidence to support the importance of IGF-2 and IGF-1R overexpression in tumourigenesis. The inappropriate production of IGF-2 in these oral squamous carcinoma cells represents an important pathway which may be exploited by malignant cells to evade targeted cell elimination.

\section{Acknowledgements}

The authors are grateful to the British Association of Oral and Maxillofacial Surgeons for grant support to G.B.

\section{References}

1. Wu H, Yu U, Amos CL, Hong WK and Spitz MR: Joint effect of insulin-like growth factors and mutagen sensitivity in lung cancer risk. J Natl Cancer Inst 92: 737-743, 2000.

2. Oh Y: IGFBPs and neoplastic models. New concepts for roles of IGFs in regulation of cancer cell growth. J Endocrinol 1: 111-113, 1997.

3. Foulstone E, Prince S, Zaccheo O, Burns JL, Harper J and Jacobs C: Insulin-like growth factor ligands, receptors, and binding proteins in cancer. J Pathol 205: 145-153, 2005.

4. Leroith D and Roberts CT Jr: The insulin-like growth factor system and cancer. Cancer Lett 195: 127-137, 2003.

5. Clemmons DR: Insulin-like growth factor binding proteins and their role in controlling IGF actions. Cytokine Growth Factor Rev 8: 45-62, 1997.

6. Ranke MB and Elmlinger M: Functional role of the insulin-like growth factor binding proteins. Horm Res 48S: 9-15, 1997.

7. Baxter RC, Binoux MA, Clemmons DR, et al: Recommendations for nomenclature of the insulin-like growth factor binding protein superfamily. Endocrinology 139: 4036, 1998.

8. Hwa V, Oh Y and Rosenfeld RG: The insulin-like growth factorbinding protein (IGFBP) superfamily. Endocr Rev 20: 761-787, 1999.
9. Leroith D: The insulin-like growth factor system. Exp Diab Res 205: 205-212, 2003.

10. O'Connor R: Regulation of IGF-I receptor signaling in tumor cells. Horm Metab Res 35: 771-777, 2003.

11. Larsson O, Girnita A and Girnita L: Role of insulin-like growth factor 1 receptor signalling in cancer. Br J Cancer 92: 2097-2101, 2005.

12. Hankinson SE, Willett WC, Colditz GA, Hunter DJ, Michaud DS and Deroo B: Circulating concentrations of insulin-like growth factor-1 and the risk of breast cancer. Lancet 351: 1993-1996, 1998.

13. Chan JM, Stampfer MJ, Giovannucci E, Gann PH, Ma P and Wilkinson P: Plasma insulin-like growth factor- 1 and prostate cancer: a prospective study. Science 279: 563-566, 1998.

14. Hassan $\mathrm{AB}$ and Macaulay VM: The insulin-like growth factor system as a therapeutic target in colorectal cancer. Ann Oncol 13: 349-356, 2002.

15. Pollack MN, Scherbhammer ES and Hankinson SE: Insulinlike growth factors and neoplasia. Nat Rev Cancer 4: 505-518, 2004.

16. Ohlsson R: Loss of IGF2 imprinting: mechanisms and consequences. Novartis Found Symp 262: 265-268, 2004.

17. Bhatavdekar JM, Patel DD, Vora HH and Balar DB: Circulating markers and growth factors as prognosticators in men with advanced tongue cancer. Tumour Biol 14: 55-58, 1994.

18. Papadimitrakopoulou VA, Brown EN, Liu DD El-Naggar AK, Jack Lee J, Hong WK and Lee HY: The prognostic role of loss of insulin-like growth factor-binding protein-3 expression in head and neck carcinogenesis. Cancer Lett 239: 136-143, 2006.

19. Brady G, O'Regan E, Miller I, Ogungbowale A, Kapas S and Crean SJ: Serum levels of insulin like growth factors (IGFs) and their binding proteins (IGFBP's) $-1,-2,-3$, in oral cancer. Int $\mathbf{J}$ Maxillofac Surgery 36: 259-262, 2007.

20. Joseph BK, Savage NW, Daley TJ and Young WG: In situ hybridization evidence for a paracrine/autocrine role for insulinlike growth factor-I in tooth development. Growth Factors 13: $11-17,1996$.

21. Han X and Amar S: IGF-1 signaling enhances cell survival in periodontal ligament fibroblasts vs. gingival fibroblasts. J Dent Res 82: 454-459, 2002.

22. Tsai C-H, Yang S-F, Chen Y-J, Chou M-Y and Chang Y-C: The upregulation of insulin-like growth factor-1 in oral submucous fibrosis. Oral Oncol 41: 940-946, 2005.

23. Neuvians TP, Gashaw I, Hasenfus A, Häcker A, Winterhager E and Grobholz R: Differential expression of IGF components and insulin receptor isoforms in human seminoma versus normal testicular tissue. Neoplasia 7: 446-456, 2005.

24. Coombs NG, Gough AC and Primrose AJ: Optimisation of DNA and RNA from archival formalin-fixed tissue. Nucleic Acids Res 27: E12, 1999.

25. Hagi-Pavli E, Farthing PM, Henshaw FN and Kapas S: Presentation of ICAM- 1 protein at the cell surface of oral keratinocytes in the presence of adrenomedullin and corticotrophin. Cell Physiol Biochem 15: 167-174, 2005.

26. Lourenco SV and Kapas S: Integrin expression in developing human salivary glands. Histochem Cell Biol 124: 391-399, 2005.

27. Costigan DC, Guyda HJ and Posner BL: Free insulin-like growth factor-I (IGF-I) and IGF-II in human saliva. J Clin Endocrinol Metab 66: 1014-1018, 1998.

28. Amanso O and Iseki S: Expression, localization and development regulation of insulin-like growth factor I mRNA in rat submandidular gland. Arch Oral Biol 38: 671-677, 1993.

29. Kerr M, Lee A, Wang PL, Purushotham KR, Chegini N and Yamamoto H: Detection of insulin and insulin-like growth factors I and II in saliva and potential synthesis in the salivary glands of mice. Effects of type I diabetes mellitus. Biochem Pharmacol 49: 1521-1531, 1995.

30. Steller MA, Delgado CH, Bartels CJ, Woodworth CD and Zou Z: Overexpression of the insulin-like growth factor-1 receptor and autocrine stimulation in human cervical cancer cells. Cancer Res 56: 1761-1765, 1996.

31. Steller MA, Delgado $\mathrm{CH}$ and Zou Z: Insulin-like growth factor II mediates epidermal growth factor-induced mitogenesis in cervical cancer cells. Proc Natl Acad Sci USA 92: 11970-11974, 1995.

32. Baserga R, Sell C, Porcu P and Rubini M: The role of the IGF-I receptor in the growth and transformation of mammalian cells. Cell Prolif 27: 63-71, 1994. 
33. Murphy SK, Huang Z, Wen Y, Spillman MA, Whitaker RS and Simel LR: Frequent IGF2/H19 domain epigenetic alterations and elevated IGF2 expression in epithelial ovarian cancer. Mol Cancer Res 4: 283-292, 2006.

34. Pavelic K, Bukovic D and Pavelic J: The role of insulin-like growth factor 2 and its receptors in human tumors. Mol Med 8: 771-780, 2002.

35. Samani AA, Yakar S, Leroith D and Brodt P: The role of the IGF system in cancer growth and metastasis: overview and recent insights. Endocr Rev 28: 20-47, 2007.

36. Quinn KA, Treston AM, Unsworth EJ, Miller MJ, Vos M and Grimley C: Insulin-like growth factor expression in human cancer cell lines. J Biol Chem 271: 11477-11483, 1996.

37. Shaw RJ, Brown JS, Woolgar JA, Lowe D, Rogers SN and Vaughan ED: The influence of the pattern of mandibular invasion on recurrence and survival in oral squamous cell carcinoma. Head Neck 26: 861-869, 2004.

38. Manuel S, Raghavan SK, Pandey M and Sebastian P: Survival in patients under 45 years with squamous cell carcinoma of the oral tongue. Int J Oral Maxillofac Surg 32: 167-173, 2003.

39. Gasparoni A, Fonzi L, Schneider GB, Wertz PW, Johnson GK and Squier CA: Comparison of differentiation markers between normal and two squamous cell carcinoma cell lines in culture. Arch Oral Biol 49: 653-664, 2004.
40. Weber A, Hengge UR, Stricker I, et al: Protein microarrays for the detection of biomarkers in head and neck squamous cell carcinomas. Human Pathol 38: 228-238, 2007.

41. Jerome L, Shiry L and Leyland-Jones B: Deregulation of the IGF axis in cancer: epidemiologival evidence and potential therapeutic interventions. Endo-Related Cancer 10: 561-578, 2003.

42. Yee D: Targeting insulin-like growth factor pathways. Br J Cancer 94: 465-468, 2006.

43. Miller BS and Yee D: Type I insulin-like growth factor receptor as a therapeutic target in cancer. Cancer Res 65: 10123-10127, 2005.

44. Hofmann F and Garcia-Echeverria C: Blocking the insulin-like growth factor-I receptor as a strategy for targeting cancer. Drug Discov Today 10: 1041-1047, 2005.

45. Butler AA, Blakesley VA, Poulaki V, et al: Stimulation of tumor growth by recombinant human insulin-like growth factor-I (IGF-I) is dependent on the dose and the level of IGF-I receptor expression. Cancer Res 58: 3021-3027, 1998.

46. Baserga R: The IGF-I receptor in cancer research. Exp Cell Res 253: 1-6, 1999. 